\title{
Electric Power Research Institute Environmental Control Technology Center Report to the Steering Committee
}

\section{Topical Report August 1997}

Work Performed Under Contract No.: DE-FG22-94PC93256

\author{
For \\ U.S. Department of Energy \\ Office of Fossil Energy \\ Federal Energy Technology Center \\ P.O. Box 880 \\ Morgantown, West Virginia 26507-0880
}

\author{
By \\ EPRI ECTC \\ 7725 Lake Road
}

Barker, New York 14012 


\section{Disclaimer}

This report was prepared as an account of work sponsored by an agency of the United States Government. Neither the United States Government nor any agency thereof, nor any of their employees, makes any warranty, express or implied, or assumes any legal liability or responsibility for the accuracy, completeness, or usefulness of any information, apparatus, product, or process disclosed, or represents that its use would not infringe privately owned rights. Reference herein to any specific commercial product, process, or service by trade

name, trademark, manufacturer, or otherwise does not necessarily constitute or imply its endorsement, recommendation, or favoring by the United States Government or any agency thereof. The views and opinions of authors expressed herein do not necessarily state or reflect those of the United States Government or any agency thereof. 


\section{DISCLAIMER}

This report was prepared as an account of work sponsored by an agency of the United States Government. Neither the United States Government nor any agency thereof, nor any of their employees, makes any warranty, express or implied, or assumes any legal liability or responsibility for the accuracy, completeness, or usefulness of any information, apparatus, product, or process disclosed, or represents that its use would not infringe privately owned rights. Reference herein to any specific commercial product, process, or service by trade name, trademark, manufacturer, or otherwise does not necessarily constitute or imply its endorsement, recommendation, or favoring by the United States Government or any agency thereof. The views and opinions of authors expressed herein do not necessarily state or reflect those of the United States Government or any agency thereof.

\section{CAUTIONS TO USE OF THIS REPORT}

This report is a compilation of monthly progress reports by EPRI contractors (Radian International, Parsons Power) connected with the Environmental Control Technology Center (ECTC). This report is intended to provide timely information regarding the status of testing and research to the ECTC co-sponsoring organizations. All data, results, and remarks contained in this report should be considered preliminary based on the information available to date. Any speculation or conclusions discussed in this report are subject to change as additional information becomes available.

Neither EPRI, members of EPRI, Radian International, Parsons Power, or any person acting on behalf of any of them makes any warranty, express or implied, with respect to the use of any information, apparatus, method, or process disclosed in this report, or that any such use may not infringe privately owned rights. Neither EPRI, members of EPRI, Radian International, Parsons Power, or any person acting on behalf of any of them assumes any liabilities with respect to the use of, or for damages resulting from the use of any information, apparatus, method, or process disclosed in this report.

For further information on:

Facility Operations and Miscellaneous ECTC inquires; contact - Gary Andes (716) 795-3397

Wet FGD/Toxics Testing, Spray Drying/Dry FGD/Duct Injection technologies; contact - Richard Rhudy (415) 855-2421

Air Toxics/Carbon Injection for Mercury Control contact - Ramsay Chang (415) 855-2535 


\section{TABLE OF CONTENTS}

I. EXECUTIVE SUMMARY

II. FACILITY STATUS

- General

- Carbon Injection System

- Financial Report

III. PILOT AND MINI-PILOT TEST ACTIVITY

- Testing Overview

- Summary of Operations

- Summary of Results

- Future Testing

IV. APPENDIX A Test Schedule(s)

V. APPENDIX B Process/Analytical Data Summary 


\section{EXECUTIVE SUMMARY}

\section{General Operations}

Operations and maintenance continued this month at the Electric Power Research Institute's (EPRI's) Environmental Control Technology Center (ECTC). Testing for the month involved the Dry Sorbent Injection (DSI) test block with the Carbon Injection System.

The 1.0 MW Cold-Side Selective Catalytic Reduction (SCR) unit, the 0.4 MW MiniPilot Wet Scrubber, and the 4.0 MW Pilot Wet Scrubber remained idle this month in a cold-standby mode and were inspected regularly. These units remain available for testing as future project work is identified.

\section{Pilot Testing Highlights}

The 1990 Clean Air Act Amendments have required that the Environmental Protection Agency (EPA) assess the health risks and environmental effects associated with air toxic emissions (primarily mercury) from fossil-fuel fired utility boilers. EPRI has sponsored research on environmental mercury since 1983 to determine the factors that may influence human health, and to determine the role of electric power generating stations in contributing to those factors. Over the last four years, EPRI's Environmental Control Technology Center (ECTC) has conducted EPRI and DOE sponsored testing to develop and demonstrate appropriate measurement methods and control technologies for power plant atmospheric mercury emissions.

Building upon the experience and expertise of the EPRI ECTC, a test program was initiated at the Center in July to further evaluate dry sorbent-based injection technologies upstream of a cold-side ESP for mercury control, and to determine the effects of such sorbents on ESP performance. This program was continued in August at the ECTC, and the results will be compared to test data from previous DOE/EPRI demonstrations, and to other ongoing programs.

The primary objectives of this test program are to:

- Determine the levels of mercury removal achievable by dry sorbent injection upstream of an electrostatic precipitator (ESP). The process parameters to be investigated include sorbent residence time, sorbent type, sorbent size, sorbent loading, and flue gas temperature.

- Determine the impact of sorbent injection on ESP performance. 


\section{FACILITY STATUS}

\section{General}

The NYSEG Kintigh Station provided flue gas to the Center $100 \%$ of the time during this performance period. As the Kintigh Station operated with a variety of coals, fluctuations in the Center's inlet $\mathrm{SO}_{2}$ concentrations were experienced.

Safety training for the month was conducted by the Operations Manager. A safety video entitled "Basic Ergonomics" was reviewed and discussed with the staff. Inspections of the ECTC Facility and safety equipment (SCR air-packs, fire extinguishers, etc.) were completed and recorded this month. All systems were found to be in good condition. By continuing to emphasize safe work habits at the Center, we have raised the total number of days without a lost time injury to 1914 as of $8 / 31 / 97$.

The monthly safety meeting with the NYSEG Kintigh Station and the EPRI ECTC was held on August 28, 1997 to exchange information and cover joint safety issues. The major points of discussion included the future plans for the ECTC $\mathrm{SO}_{2}$ spiking system, and the Phase I environmental site assessment of the ECTC.

\section{Pilot and Mini-Pilot Testing}

The equivalent and actual availability for the ECTC Carbon Injection System was $81 \%$ during this period. The System was off-line during the following periods this month:

- August 11-12 for 19 hours to inspect the SDA flue gas heater.

- August 13-15 for 76 hours to repair air leaks in the ESP hotdeck.

The Dry Sorbent Injection (DSI) test block continued this month with tests DSI-4; DSI-4a; DSI-4b; DSI-4c; and DSI-5. The objective of this test block is to study the ECTC electrostatic precipitator (ESP) performance and removal efficiency for total mercury as activated carbon and other sorbents are injected across the ESP. For this testing, the ECTC flue gas path was configured so that the particulate and acid-gas rich dirty raw gas (DRG) from the facility inlet flows through the Spray Dryer Absorber (SDA) for temperature control, and then through the ESP and the ECTC outlet ductwork.

During the test block, various sorbents are to be injected upstream of the ESP at several different loading rates as the flue gas is sampled for particulate (method 5), $\mathrm{SO}_{2} / \mathrm{O}_{2}$ (ECTC CEMs), and total mercury (method 101A). The mercury samples collected during the testing this period were forwarded to Radian International for off-site analysis; ash samples from the ESP and the ECTC ash silo, and coal samples from the Kintigh Station, were collected weekly for archiving and analysis at a later date. The operational parameters for the DSI testing with the Carbon Injection System this period included: gas flow of 10,200 scfm; inlet $\mathrm{SO}_{2}$ concentration as received from the Kintigh Station; ESP outlet particulate loading of 0.1-0.2 lb./MBtu; 
ESP inlet flue gas temperatures of 275 and $300^{\circ} \mathrm{F}$; and activated carbon injection rates of $10 \mathrm{lb}$./Macf.

The following maintenance work was completed on the Carbon Injection System this performance period:

- The SDA flue gas heater was inspected.

- The ESP hotdeck/crock inspection revealed that a majority of the crock covers were leaking. These covers were resealed and the inleakage was resolved.

- Various adjustments were made to the ESP field settings to maintain the proper outlet particulate emissions for the test block.

- Various CEM inspection/calibrations were complete.

- The SDA atomizer was inspected and readied for operation.

- The ECTC sump pump drive motor was replaced.

- All normal and routine scheduled maintenance was completed on the ECTC facility equipment.

- The activated carbon feeder was inspected and calibrated.

- A power supply was replaced on OpCon 210 in the WDPF system.

\section{Financial Report}

The Financial Report for the four Operations and Maintenance contract tasks are summarized below for the month of August 1997, the year to date, and the contract total.

Task Definitions:

Task 100: Operations and Maintenance Labor

Task 200: Purchased Materials

Task 300: Engineering Support

Task 400: Training

Table i.

Monthly Operating Costs by Task

\begin{tabular}{|c|c|c|c|c|c|c|}
\hline & \multicolumn{2}{|c|}{ "August } & \multicolumn{2}{|c|}{ Year to Date } & \multicolumn{2}{|c|}{$\overline{\text { Contract Total }}$} \\
\hline Task 100 & $\$$ & 53,164 & $\$$ & 200,745 & $\$$ & $14,679,754$ \\
\hline Task 200 & $\$$ & 7,954 & $\$$ & 45,047 & $\$$ & $8,556,242$ \\
\hline Task 300 & $\$$ & 18,598 & $\$$ & 81,776 & $\$$ & $1,276,364$ \\
\hline Task 400 & $\$$ & - & $\$$ & 63 & $\$$ & 53,298 \\
\hline DOE Grant & $\$$ & - & $\$$ & 132,616 & $\Phi$ & 248,792 \\
\hline TOTAL & $\$$ & 79,716 & $\$$ & 460,247 & $\$$ & $24,814,450$ \\
\hline
\end{tabular}


The attached graph illustrates the budgeted and actual expenses for ECTC O\&M activities through August 1997.

Figure i.

1997 Operation \& Maintenance Costs

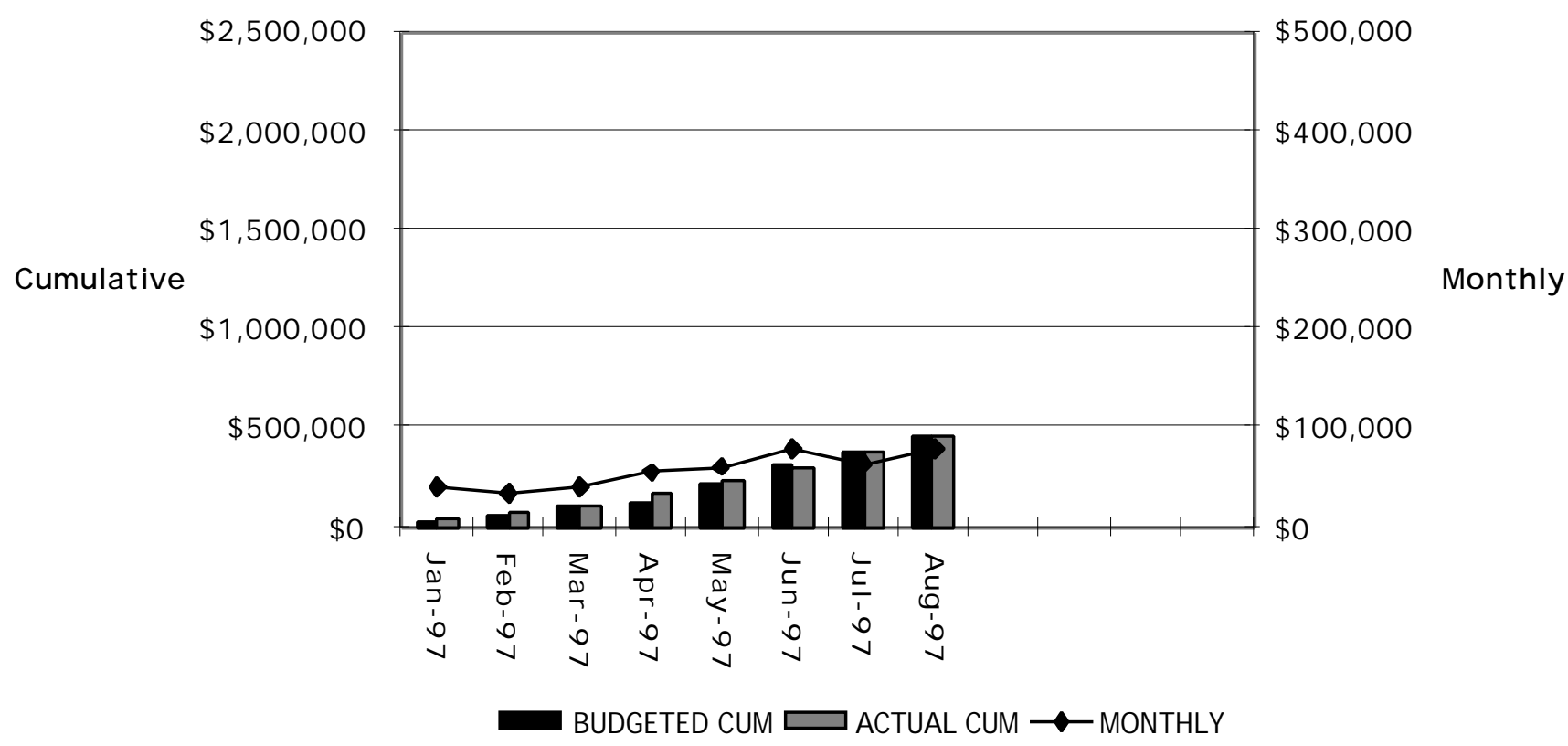




\section{PILOT AND MINI-PILOT TEST ACTIVITY}

\section{Testing Overview}

The 1990 Clean Air Act Amendments have required that the Environmental Protection Agency (EPA) assess the health risks and environmental effects associated with air toxic emissions (primarily mercury) from fossil-fuel fired utility boilers. EPRI has sponsored research on environmental mercury since 1983 to determine the factors that may influence human health, and to determine the role of electric power generating stations in contributing to those factors. Over the last four years, EPRI's Environmental Control Technology Center (ECTC) has conducted EPRI and DOE sponsored testing to develop and demonstrate appropriate measurement methods and control technologies for power plant atmospheric mercury emissions.

Building upon the experience and expertise of the EPRI ECTC, a test program was initiated at the Center in July to further evaluate dry sorbent-based injection technologies upstream of a cold-side ESP for mercury control, and to determine the effects of such sorbents on ESP performance. The results from this program will be compared to the results from previous DOE/EPRI demonstrations, and to other ongoing programs.

The primary objectives of this test program are to:

- Determine the levels of mercury removal achievable by dry sorbent injection upstream of an electrostatic precipitator (ESP). The process parameters to be investigated include sorbent residence time, sorbent type, sorbent size, sorbent loading, and flue gas temperature.

- Determine the impact of sorbent injection on ESP performance. 


\section{Summary of Operations}

The Dry Sorbent Injection (DSI) test block with the Pilot Spray Dryer Absorber (SDA) and electrostatic precipitator (ESP) began during the first week of July and continued through August. The process configuration for this testing (with sampling and injection points) is shown below in Figure 1.

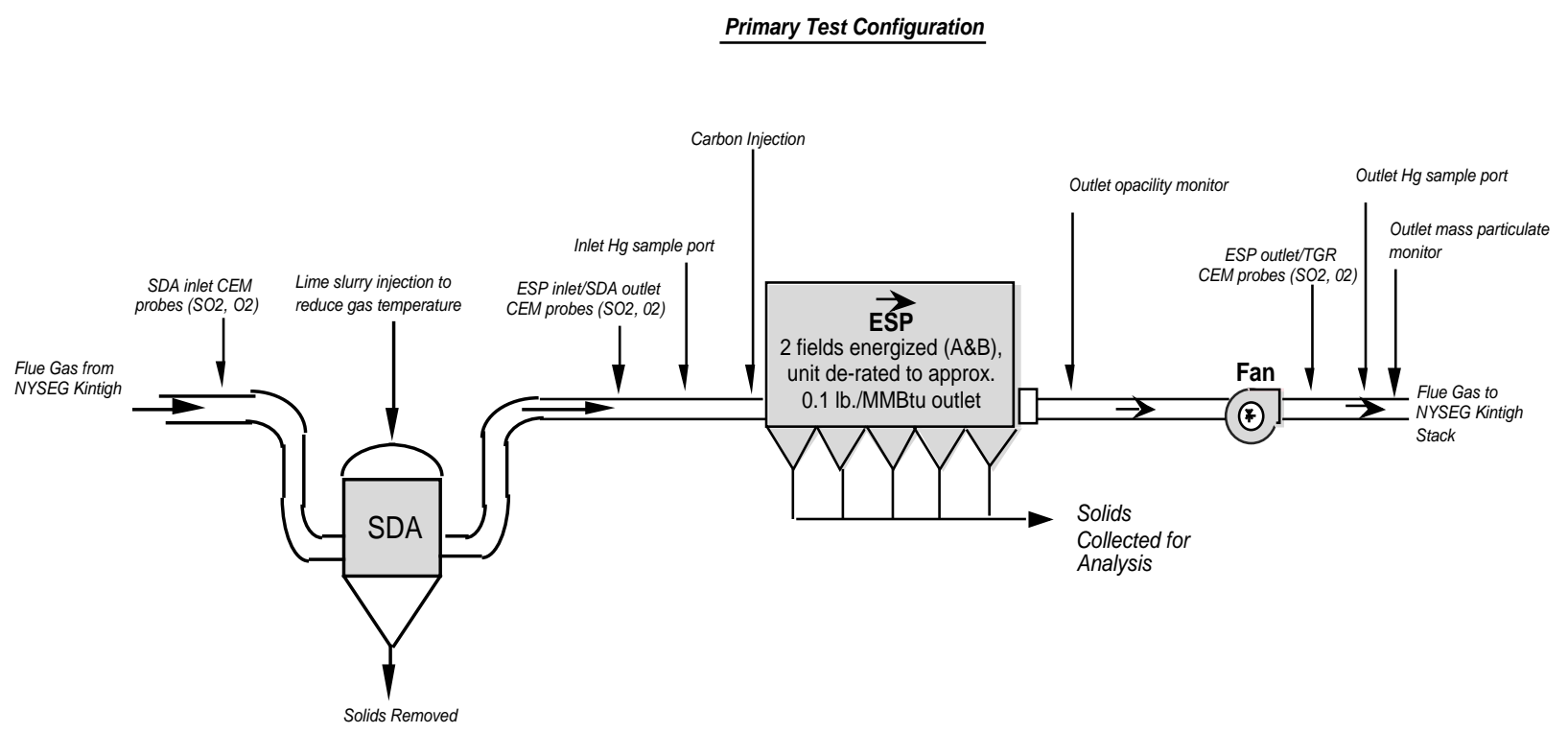

Figure 1. Process Flow Diagram for Dry Sorbent Injection (DSI) Test Block

During this test program, a commercial carbon based sorbent (activated FGD carbon from American Norit) was studied for injection into the ECTC flue gas stream for mercury control. At the Center, testing was conducted primarily across the cold-side ESP (5.0 MW equivalent gas flow). For this testing, the ECTC ESP was configured to simulate a retrofit application utilizing a small (1-2 field) unit; the ESP was also calibrated and detuned to produce a baseline outlet mass particulate emission of 0.1$0.2 \mathrm{lb}$./MBtu. Upstream of the ESP, the flue gas mercury concentration was measured using EPA Method 101A. Several of the other inlet flue gas parameters/species $\left(\mathrm{SO}_{2}, \mathrm{O}_{2}, \mathrm{HCl}\right.$, etc.) were also continuously monitored and adjusted to meet testing requirements and determine their effects on mercury removal.

Downstream from the ESP inlet sampling point, the activated carbon was injected into the ESP with mercury sampling at the ESP outlet to determine removal efficiency. Periodic sampling of the collected flyash/carbon solids was also conducted to help determine particulate removal efficiencies across the ESP, and to determine the impact of carbon injection on flyash loss on ignition (LOI). Also, with the characterization data on the inlet flue gas composition and monitoring of the ESP operation, the particulate collection efficiency of the ESP was recorded to determine any degradation effects as the activated carbon was injected into the system. 
During this month, testing at an ESP inlet flue gas temperature of $300^{\circ} \mathrm{F}$ was concluded as 4 more samples were collected at $10 \mathrm{lb}$./Macf. Also, during this period, it was determined that there were some installation problems with the mass particulate monitor (ESC P-5A) in service for ESP performance data. Adjustments were made to the unit installation, and it was calibrated and returned to service.

As testing continued in August, correlations were made between the output data from the ESC P-5A and the data from regular EPA Method 5 samples so that the P-5A unit could be used to evaluate the ESP outlet loading on a continuous basis. The ESP hot deck was also inspected this month due to high $\mathrm{O}_{2}$ inleakage data across the ESP and the possibility of leaking crocks. After the inspection, the hot deck crocks were resealed and the high inleakage was resolved. As testing resumed, the test matrix continued at an ESP inlet flue gas temperature of $275^{\circ} \mathrm{F}$ and a carbon injection rate of $10 \mathrm{lb}$./Macf through the end of the month. A summary of the operating conditions in August is presented in Table 1.

\section{Table 1. August 1997 Dry Sorbent Injection (DSI) Operating Summary}

\begin{tabular}{|c|c|c|}
\hline Date & Test Description & Operating Summary \\
\hline $\begin{array}{l}\text { Fri. } \\
\text { Aug. 1.97 }\end{array}$ & $\begin{array}{l}\text { DSI-4: Carbon } \\
\text { Injection }(10,200 \mathrm{scfm}, \\
\left.300^{\circ} \mathrm{F}, 9.2 \mathrm{lb} / \mathrm{hr}\right) \\
\text { ESP A (10) }\end{array}$ & $\begin{array}{l}\text { Carbon through the night ranged from } 8 \mathrm{lb} . / \mathrm{hr} \text { to } 10 \\
\mathrm{lb} . / \mathrm{hr} \text {. Sampling console problems, with heated box } \\
\text { heater, needed to be replaced. Started Methods } 101 \mathrm{~A} \\
\text { run } \# 1 \text { at } 8: 50 \text { at a carbon rate of } 9.04 \mathrm{lb} / \mathrm{hr} \text {, run } \# 2 \text { was } \\
\text { started at } 10: 00 \text {, and finished at } 11: 00 \text { with a carbon } \\
\text { rate of } 9.10 \mathrm{lb} / \mathrm{hr} \text {. At 11:25 carbon was turned off. The } \\
\text { ESP was kept up to see how long it took to return to } \\
\text { baseline after carbon was turned off. It took about } 1 \\
\text { hour to return to baseline. ESP was started on purge air } \\
\text { at } 12: 50 \text {, and isolated from NYSEG at } 13: 50 \text {. } 3000 \mathrm{lb} \text { of } \\
\text { carbon ordered, and won't be shipped until } 8 / 9 \text { or at } \\
\text { the latest } 8 / 14 \text {. }\end{array}$ \\
\hline $\begin{array}{l}\text { Mon. } \\
\text { Aug. 4, } 97\end{array}$ & $\begin{array}{l}\text { DSI-4a }(10,200 \mathrm{scfm}, \\
\left.300^{\circ} \mathrm{F}, 9.2 \mathrm{lb} / \mathrm{hr}\right) \\
\text { ESP A }(10)\end{array}$ & $\begin{array}{l}\text { I\&C in at } 04: 00 \text { to calibrate opacity monitor, CEMs, } \\
\text { and P5-A. Waiting for NYSEG to level out and } \\
\text { Electrician to check ESP readings. Started Method } 5 \\
\text { at 8:50 at ESP outlet. Finished at 10:29 with the mass } \\
\text { loading of } 0.176 \mathrm{lb} / \mathrm{MMBtu} \text {. This will be the setting } \\
\text { that is used for next set of carbon injection test. Carbon } \\
\text { was started up at 13:00 at } 9.2 \mathrm{lb} / \mathrm{hr} \text { to see ESP } \\
\text { performance response with this loading and NYSEG at } \\
700 \mathrm{MW} \text {, and carbon was turned off at 14:00. This test } \\
\text { resulted in an increase in opacity and P5-A readings } \\
\text { and a voltage on "A" field lowered. A contractors } \\
\text { meeting was held at 14:00. Plans for next couple weeks } \\
\text { were discussed for use of time and on-site carbon. }\end{array}$ \\
\hline $\begin{array}{l}\text { Tue. } \\
\text { Aug. 5, } 97\end{array}$ & $\begin{array}{l}\text { DSI-4a }(10,200 \mathrm{scfm}, \\
\left.300^{\circ} \mathrm{F}, 9.2 \mathrm{lb} / \mathrm{hr}\right) \\
\text { ESP A }(10)\end{array}$ & $\begin{array}{l}\text { Work out correlation between Method } 5 \text { stack sampling } \\
\text { and P5-A reading. Obtain correction factor to put into } \\
\text { WDPF. From existing data between P5-A and mass } \\
\text { loading the correction factor range from } 3-1 \text {. Will } \\
\text { calibrate P5-A, run a Method } 5 \text { and record } 5 \text { min. } \\
\text { average values during sampling. Hopefully get an } \\
\text { accurate reading to correlate, and input a correction } \\
\text { factor into the WDPF. }\end{array}$ \\
\hline
\end{tabular}


Table 1. August 1997 Dry Sorbent Injection (DSI) Operating Summary (cont.)

\begin{tabular}{|c|c|c|}
\hline Date & Test Description & Operating Summary \\
\hline $\begin{array}{l}\text { Wed. } \\
\text { Aug. 6, } 97\end{array}$ & $\begin{array}{l}\text { DSI-4a }(10,200 \mathrm{scfm}, \\
\left.300^{\circ} \mathrm{F}, 9.2 \mathrm{lb} / \mathrm{hr}\right) \\
\text { ESP A }(10)\end{array}$ & $\begin{array}{l}\text { The P-5A was calibrated at } 07: 30 \text { by the I\&C } \\
\text { department. A method } 5 \text { was started at 9:00, along } \\
\text { with recording } 5 \text { min. average readings for the sample } \\
\text { period. The Method } 5 \text { was completed at } 10: 30 \text {. This } \\
\text { mass loading resulted in a } 0.188 \mathrm{lb} / \mathrm{MMBtu} \text { value. } \\
\text { After looking into the inconsistent P-5A values, it was } \\
\text { determined that the unit was not installed properly. } \\
\text { The P-5A requires } 36 \text { inches from the duct center to the } \\
\text { back duct wall for the focal point to be at the center of } \\
\text { the duct. These adjustments will be made on Friday } \\
\text { when the facility is off line. }\end{array}$ \\
\hline $\begin{array}{l}\text { Thur. } \\
\text { Aug. 7,97 }\end{array}$ & $\begin{array}{l}\text { DSI-4b }(10,200 \mathrm{scfm}, \\
\left.300^{\circ} \mathrm{F}, 9.2 \mathrm{lb} / \mathrm{hr}\right) \\
\text { ESP A }(10)\end{array}$ & $\begin{array}{l}\text { With the P-5A not properly installed the day was } \\
\text { used to see if the carbon had an effect on mass loading. } \\
\text { The carbon injector was started at } 6: 00 \text { at a rate of } 9.2 \\
\mathrm{lb} / \mathrm{hr} \text {. The Method } 5 \text { was started at } 7: 30 \text {, allowing for } \\
\text { the carbon to "season" the ESP. P-5A, NYSEG loading, } \\
\text { and opacity were tracked during sampling. The } \\
\text { Method } 5 \text { was completed at 9:00, resulting in a mass } \\
\text { loading of } 0.170 \mathrm{lb} / \mathrm{MMBtu} \text {. A darker color was } \\
\text { noticed on the filter from the carbon. The carbon did } \\
\text { not seem to effect the mass loading, is comparable to } \\
\text { the previous days loading. The facility was shut } \\
\text { down to allow for changes to be made to duct work to } \\
\text { install the P-5A tomorrow. }\end{array}$ \\
\hline $\begin{array}{l}\text { Fri. } \\
\text { Aug. 8, } 97\end{array}$ & $\begin{array}{l}\text { DSI-4b }(10,200 \mathrm{scfm}, \\
\left.300^{\circ} \mathrm{F}, 9.2 \mathrm{lb} / \mathrm{hr}\right) \\
\text { ESP A }(10)\end{array}$ & $\begin{array}{l}\text { Duct changes made. A } 24 \text { inch extension was added, to } \\
\text { allow for proper focal length on the P-5A instrument. } \\
\text { The blank flange was painted flat black and then } \\
\text { insulated. Received some of the } \mathrm{Hg} \text { analysis numbers } \\
\text { from Radian. A conference meeting was held at } 11: 30 \\
\text { with R. Chang. Testing for the past and up coming } \\
\text { week were discussed. }\end{array}$ \\
\hline
\end{tabular}


Table 1. August 1997 Dry Sorbent Injection (DSI) Operating Summary (cont.)

\begin{tabular}{|c|c|c|}
\hline Date & Test Description & Operating Summary \\
\hline $\begin{array}{l}\text { Mon. } \\
\text { Aug. 11, } 97\end{array}$ & $\begin{array}{l}\text { DSI-4b }(10,200 \mathrm{scfm}, \\
\left.300^{\circ} \mathrm{F}, 9.2 \mathrm{lb} / \mathrm{hr}\right) \\
\text { ESP A }(10)\end{array}$ & $\begin{array}{l}\text { I\&C came in at } 4: 00 \text { to calibrate the CEMs, opacity } \\
\text { monitor and the P-5A. Had some difficulty with the } \\
\text { P-5A. A Method } 5 \text { was started at } 8: 30 \text {, along with } \\
\text { recording } 5 \text { min. averages of opacity, NYSEG loading } \\
\text { and P-5A. The mass loading was finished at } 10: 00 \text { and } \\
\text { the result showed a loading of } 0.208 \mathrm{lb} / \mathrm{MMBtu} \text {. This } \\
\text { associated with a WDPF correction factor of } 0.53 \text {. It } \\
\text { was noticed that the fan output had increased, hot } \\
\text { deck temperatures were lower, and purge air increased. } \\
\text { A blockage is suspect on the SDA inlet heater. } \\
\text { Something is causing the hot deck not to reach } \\
\text { temperature, ambient air is being introduced. There } \\
\text { seems to be an increasing noise at the inlet to the } \\
\text { heater. The facility is shut down at } 14: 00 \text { to cool off } \\
\text { duct work, so that the heater can be opened in the } \\
\text { morning. Received the rest of the mercury analysis } \\
\text { numbers. }\end{array}$ \\
\hline $\begin{array}{l}\text { Tue. } \\
\text { Aug. 12, } 97\end{array}$ & $\begin{array}{l}\text { DSI-4b }(10,200 \mathrm{scfm}, \\
\left.300^{\circ} \mathrm{F}, 9.2 \mathrm{lb} / \mathrm{hr}\right) \\
\text { ESP A }(10)\end{array}$ & $\begin{array}{l}\text { The SDA heater was opened first thing in the morning } \\
\text { and no blockage was found. The noise was most likely } \\
\text { from some broken heater framing and a few corroded } \\
\text { elements. Also opened the man way between the DRG } \\
\text { header and the heater, this was also clean. The SDA } \\
\text { inlet was checked too, nothing found. The facility was } \\
\text { brought up on gas, to do a pressure profile of the gas } \\
\text { configuration. The pressure profile showed no drastic } \\
\text { pressure drops in the system that would be caused by a } \\
\text { plugged duct. The facility will be kept up over night } \\
\text { to do a method } 5 \text { for P-5A calibration in the morning } \\
\text { then be shut down. The facility will be allowed to } \\
\text { cool, and then the hot deck will be inspected for leaks. }\end{array}$ \\
\hline $\begin{array}{l}\text { Wed. } \\
\text { Aug. 13, } 97\end{array}$ & $\begin{array}{l}\text { DSI-4b }(10,200 \mathrm{scfm}, \\
\left.300^{\circ} \mathrm{F}, 9.2 \mathrm{lb} / \mathrm{hr}\right) \\
\text { ESP A }(10)\end{array}$ & $\begin{array}{l}\text { The P-5A and opacity monitor were calibrated at 7:00. } \\
\text { A Method } 5 \text { was started at 9:00, along with recording } 5 \\
\text { min. averages for opacity, NYSEG loading, and P-5A. } \\
\text { This mass loading showed a } 0.221 \mathrm{lb} / \mathrm{MMBtu} \text { result, } \\
\text { that gave a WDPF correction factor of .60 for the P-5A. } \\
\text { At 11:00 the facility was purged. The ESP hot deck } \\
\text { was opened up and will be allowed to cool overnight. }\end{array}$ \\
\hline $\begin{array}{l}\text { Thur. } \\
\text { Aug. 14, } 97\end{array}$ & $\begin{array}{l}\text { DSI-4b }(10,200 \mathrm{scfm}, \\
\left.300^{\circ} \mathrm{F}, 9.2 \mathrm{lb} / \mathrm{hr}\right) \\
\text { ESP A }(10)\end{array}$ & $\begin{array}{l}\text { The facility is down for hot deck inspection. After } \\
\text { entering the hot deck of the ESP, it was noticed that } \\
\text { many of the silicone seals around the plates on the } \\
\text { crocks had crack and were dried out. The plates were } \\
\text { caulked } 2 \text { per crock and } 40 \text { crocks. The hot deck was } \\
\text { closed up on afternoon shift and the silicone was aloud } \\
\text { to set and dry overnight. }\end{array}$ \\
\hline
\end{tabular}


Table 1. August 1997 Dry Sorbent Injection (DSI) Operating Summary (cont.)

\begin{tabular}{|c|c|c|}
\hline Date & Test Description & Operating Summary \\
\hline $\begin{array}{l}\text { Fri. } \\
\text { Aug. 15, } 97\end{array}$ & $\begin{array}{l}\text { DSI-4b }(10,200 \mathrm{scfm}, \\
\left.300^{\circ} \mathrm{F}, 9.2 \mathrm{lb} / \mathrm{hr}\right) \\
\text { ESP A (10) }\end{array}$ & $\begin{array}{l}\text { The facility is down due to hot deck repairs. The ESP } \\
\text { heaters were turned on allowing the ESP to warm and } \\
\text { be ready to pull gas on Monday. }\end{array}$ \\
\hline $\begin{array}{l}\text { Mon. } \\
\text { Aug. 18, } 97\end{array}$ & $\begin{array}{l}\text { DSI-4c }(10,200 \mathrm{scfm}, \\
\left.300^{\circ} \mathrm{F}, 9.2 \mathrm{lb} / \mathrm{hr}\right) \\
\text { ESP A }(10)\end{array}$ & $\begin{array}{l}\text { I\&C is in at } 4: 00 \text { to calibrate opacity monitor, CEMs, } \\
\text { and P-5A. There was a problem found on the opacity } \\
\text { monitor when the unit would not cal. zero. The } \\
\text { problem was resolved and the unit put back in service } \\
\text { at } 10: 30 \text {. At } 10: 45 \text { a Method } 5 \text { was started on the ESP- } \\
\text { Outlet, along with recording } 5 \text { min. averages of } \\
\text { opacity, P-5A, and NYSEG load. The Method } 5 \text { was } \\
\text { finished at } 12: 20 \text {, and the results showed a mass } \\
\text { loading of } 0.178 \mathrm{lb} / \text { MMBtu and a correction factor of } \\
0.42 \text {. }\end{array}$ \\
\hline $\begin{array}{l}\text { Tue. } \\
\text { Aug. 19, } 97\end{array}$ & $\begin{array}{l}\text { DSI-4c }(10,200 \mathrm{scfm}, \\
\left.300^{\circ} \mathrm{F}, 9.2 \mathrm{lb} / \mathrm{hr}\right) \\
\text { ESP A }(10)\end{array}$ & $\begin{array}{l}\text { The load of the NYSEG station is low, and waiting for } \\
\text { load to build and stabilize. A correction factor was put } \\
\text { on the P-5A reading from the WDPF, using three } \\
\text { previous correlation to get } 0.52 \text {. Hoppers E-A were } \\
\text { pulled at 9:00, then carbon was started at } 9: 17 \text { at } 9.2 \\
\text { lb/hr. A Method } 5 \text { was conducted on the ESP-Inlet } \\
\text { along with using the P-5A at the ESP-Outlet. The } \\
\text { Inlet was } 4.867 \mathrm{lb} / \text { MMBtu and the Outlet was } 0.204 \\
\text { lb/MMBtu. Carbon was shut off at } 15: 45 \text {, the ESP } \\
\text { hoppers were emptied and timed. }\end{array}$ \\
\hline $\begin{array}{l}\text { Wed. Aug. } \\
20,97\end{array}$ & $\begin{array}{l}\text { DSI-4c }(10,200 \mathrm{scfm}, \\
\left.300^{\circ} \mathrm{F}, 9.2 \mathrm{lb} / \mathrm{hr}\right) \\
\text { ESP A }(10)\end{array}$ & $\begin{array}{l}\text { Carbon injection was started at } 05: 00 \text { at a rate of } 9.2 \\
\mathrm{lb} / \mathrm{hr} \text {. A solenoid valve needed to be fixed on one of } \\
\text { the towers before sampling could begin. The carbon } \\
\text { injection rate was at } 10.5 \mathrm{lb} / \mathrm{hr} \text { when the first run of } \\
\text { Method } 101 \mathrm{~A} \text { was started at } 8: 45 \text {. Run } \# 2 \text { was started } \\
\text { at 10:00 and when concluded the carbon was at } 8.95 \\
\mathrm{lb} / \mathrm{hr} \text {. Carbon injection was turned off at } 11: 30 \text {, and } \\
\text { "A" field was pulled. A voltage drop was noticed } \\
\text { when the carbon was turned off at a 11:30 ( } 55 \mathrm{~V} \text { to } 52 \mathrm{~V} \text { ). } \\
\text { This drop was not recovered after carbon had been off } \\
\text { for a while. To try and clean "A" field, over night the } \\
\text { ESP was switched to "B" field only and rapping was } \\
\text { increased on "A", then returned at } 05: 00 \text {. }\end{array}$ \\
\hline
\end{tabular}


Table 1. August 1997 Dry Sorbent Injection (DSI) Operating Summary (cont.)

\begin{tabular}{|c|c|c|}
\hline Date & Test Description & Operating Summary \\
\hline $\begin{array}{l}\text { Thur. } \\
\text { Aug. 21, } 97\end{array}$ & $\begin{array}{l}\text { DSI-4c }(10,200 \mathrm{scfm}, \\
\left.300^{\circ} \mathrm{F}, 9.2 \mathrm{lb} / \mathrm{hr}\right) \\
\text { ESP A }(10)\end{array}$ & $\begin{array}{l}\text { At } 05: 00 \text { the ESP was switched back from " } \mathrm{B} \text { " to "A" } \\
\text { field, and the rappers were reset. The lower voltage } \\
\text { was still present. The opacity monitor was cleaned, } \\
\text { and no change was recorded. A few more things were } \\
\text { tried on the ESP to clean the plates, no effect was seen. } \\
\text { The inlet temperature was raised to } 320^{\circ} \mathrm{F} \text {, and } \\
\text { increased the rappings on "A" field. Also switched to } \\
\text { only " } \mathrm{B}^{\prime \prime} \text { field. Opacity and the P-5A are also running } \\
\text { high }\left(8-11 \%, 230-280 \mathrm{mg} / \mathrm{Am}^{3}\right) \text {. At } 10: 00 \text { the inlet was } \\
\text { at } 318^{\circ} \mathrm{F}, \mathrm{NYSEG} \text { at } 700 \mathrm{MW} \text { and the voltage was at } \\
54 \mathrm{~V} \text {. The inlet temperature was then lowered back } \\
\text { down to } 300^{\circ} \mathrm{F} \text {. Voltage decreased with temperature } \\
\text { decrease. Lowered to } 52-53 \mathrm{~V} \text { at } 300^{\circ} \mathrm{F} \text {. At } 12: 00 \text { carbon } \\
\text { was started at } 9.2 \mathrm{lb} / \mathrm{hr} \text {. At } 13: 00 \text { voltage recovered to } \\
54 \mathrm{~V} \text {, opacity was at } 5.6^{\circ} \text {, and P-5A was at } 180 \\
\text { mg/Am }{ }^{3} \text {. Carbon was allowed to go until } 20: 00 \text {, then } \\
\text { the ESP inlet temperature was lowered to } 275^{\circ} \mathrm{F} \text { (using } \\
\text { dmp } 2 \text { and SDA heater). Once } 275^{\circ} \mathrm{F} \text { was reached and } \\
\text { maintained carbon was turned on at } 9.2 \mathrm{lb} / \mathrm{hr} \text {. Carbon } \\
\text { injection went for } 4 \text { hr., then shut off and the ESP inlet } \\
\text { returned to } 300^{\circ} \mathrm{F} \text {. }\end{array}$ \\
\hline $\begin{array}{l}\text { Fri. } \\
\text { Aug. 22, } 97\end{array}$ & $\begin{array}{l}\text { DSI-4c }(10,200 \mathrm{scfm}, \\
\left.300^{\circ} \mathrm{F}, 9.2 \mathrm{lb} / \mathrm{hr}\right) \\
\mathrm{ESP} A(10)\end{array}$ & $\begin{array}{l}\text { The ESP inlet was returned to } 300^{\circ} \mathrm{F} \text { and ESP settings } \\
\text { and meter readings were recorded and checked. The } \\
3000 \mathrm{lb} \text {. of Activated carbon ordered arrived. After the } \\
\text { ESP was checked out and returned to baseline, the unit } \\
\text { was shut down. }\end{array}$ \\
\hline $\begin{array}{l}\text { Mon. } \\
\text { Aug. 25, } 97\end{array}$ & $\begin{array}{l}\text { DSI-5, Carbon } \\
\text { Injection }(10,200 \mathrm{scfm} \text {, } \\
\left.275^{\circ} \mathrm{F}, 9.2 \mathrm{lb} / \mathrm{hr}\right) \mathrm{ESP} \\
\mathrm{A}, \mathrm{B}(5)\end{array}$ & $\begin{array}{l}\text { The facility was brought on line and set up to achieve } \\
10,200 \text { scfm, at } 275^{\circ} \mathrm{F} \text {, using damper } 2 \text { and SDA heater. } \\
\text { Once the inlet temperature was maintained at } 275^{\circ} \mathrm{F} \\
\text { carbon was injected at } 9.2 \mathrm{lb} / \mathrm{hr} \text { from } 11: 00-14: 00 \text {. } \\
\text { After carbon was turned off, the ESP recovered to } \\
\text { baseline readings. }\end{array}$ \\
\hline $\begin{array}{l}\text { Tue. } \\
\text { Aug. 26, } 97\end{array}$ & $\begin{array}{l}\text { DSI-5, Carbon } \\
\text { Injection }(10,200 \mathrm{scfm}, \\
\left.275^{\circ} \mathrm{F}, 9.2 \mathrm{lb} / \mathrm{hr}\right) \mathrm{ESP} \\
\mathrm{A}, \mathrm{B}(5)\end{array}$ & $\begin{array}{l}\text { At } 8: 58 \text { a Method } 5 \text { was started on the ESP outlet, } \\
\text { along with recording } 5 \text { minute averages of opacity, P- } \\
5 \mathrm{~A} \text {, and NYSEG load. The Method } 5 \text { was finished at } \\
\text { 10:28, resulting in a loading of (P-018) } 0.301 \mathrm{lb} / \mathrm{MMBt} \\
\text { and the P-5A recorded a } 0.295 \mathrm{lb} / \mathrm{MMBtu}(2 \% \text { diff). } \\
\text { Electrical made adjustments to the ESP to achieve } 0.1 \text { - } \\
0.2 \mathrm{lb} / \mathrm{MMBtu} \text {. He was not able to accomplish this } \\
\text { with just a field, and still have it be stable during } \\
\text { carbon injection. The ESP was set up with } 5 \text { on "A" and } \\
5 \text { on " } \mathrm{B}^{\prime} \text {. }\end{array}$ \\
\hline $\begin{array}{l}\text { Wed. } \\
\text { Aug. 27, } 97\end{array}$ & $\begin{array}{l}\text { DSI-5, Carbon } \\
\text { Injection }(10,200 \mathrm{scfm}, \\
\left.275^{\circ} \mathrm{F}, 9.2 \mathrm{lb} / \mathrm{hr}\right) \mathrm{ESP} \\
\mathrm{A}, \mathrm{B}(5)\end{array}$ & $\begin{array}{l}\text { A Method } 5 \text { was started at } 8: 17 \text { at the ESP outlet. The } \\
\text { Method } 5 \text { was finished at 9:47 resulting in a mass } \\
\text { loading (P-019) of } 0.104 \mathrm{lb} / \mathrm{MMBtu} \text {. Graphs were set } \\
\text { up using } \mathrm{lb} / \mathrm{hr} \text { vs. \% removal Hg. Ordered shipping } \\
\text { containers to ship out Hg samples - dual paint can box. } \\
\text { Carbon was started at 13:30 injecting } 9.2 \mathrm{lb} / \mathrm{hr} \text {. }\end{array}$ \\
\hline
\end{tabular}


Table 1. August 1997 Dry Sorbent Injection (DSI) Operating Summary (cont.)

\begin{tabular}{|l|l|l|}
\hline \multicolumn{1}{|c|}{ Date } & \multicolumn{1}{|c|}{ Test Description } & \multicolumn{1}{c|}{ Operating Summary } \\
\hline $\begin{array}{l}\text { Thur. } \\
\text { Aug. 28, } 97\end{array}$ & $\begin{array}{l}\text { DSI-5, Carbon } \\
\text { Injection }(10,200 \mathrm{scfm}, \\
\left.275^{\circ} \mathrm{F}, 9.2 \mathrm{lb} / \mathrm{hr}\right) \mathrm{ESP} \\
\mathrm{A}, \mathrm{B}(5)\end{array}$ & $\begin{array}{l}\text { Carbon injection through the night ranged from } 8.8 \text { to } \\
10.2 \mathrm{lb} / \mathrm{hr} \text {. A Method 101A was started at the ESP } \\
\text { Inlet and Outlet at 8:20 and concluded run \#2 at 10:45. } \\
\text { Carbon injection during sampling started at 10.24 and } \\
\text { ended at 10.32 lb/hr. Carbon injected through the } \\
\text { night at 9.2 lb/hr. }\end{array}$ \\
\hline $\begin{array}{l}\text { Fri. } \\
\text { Aug. 29,97 }\end{array}$ & $\begin{array}{l}\text { DSI-5, Carbon } \\
\text { Injection }(10,200 \mathrm{scfm}, \\
\left.275^{\circ} \mathrm{F}, 9.2 \mathrm{lb} / \mathrm{hr}\right) \mathrm{ESP} \\
\mathrm{A}, \mathrm{B}(5)\end{array}$ & $\begin{array}{l}\text { Carbon ran at 9.3 lb/hr to 10.79 lb/hr during the night } \\
\text { shift. At 7:50 a Method 101A was started at both the } \\
\text { inlet and outlet of the ESP. Run \#2 of the method 101A } \\
\text { was finished at 10:00, the carbon was also shut off } \\
\text { then. The ESP recovered to baseline readings at 11:00 } \\
\text { and was shut down for the weekend. }\end{array}$ \\
\hline
\end{tabular}

\section{$\underline{\text { Summary of Results }}$}

The Dry Sorbent Injection (DSI) testing this month investigated the effects of activated carbon injection (Norit FGD carbon) upstream of an ESP to determine total mercury removal efficiencies and performance effects with regard to particulate removal efficiency. Recall that FGD carbon is a lignite-based carbon material and is primarily sold as a sorbent for removal of heavy metals species in incinerator flue gas streams. The average grind size for this dry carbon powder is approximately $95 \%$ minus 325 mesh screen $(45 \mu \mathrm{m})$. The mean particle size for this FGD carbon material has been previously analyzed and reported to be approximately $15 \mu \mathrm{m}$.

To simulate full-scale operating conditions for this test block, an appropriate inlet ESP gas flow, temperature, and outlet opacity range was selected and maintained to:

- provide a representative gas/carbon residence time through the ESP;

- prevent the formation of acid gas condensation in the ESP; and,

- simulate current/future outlet opacity performance limits.

The operating conditions required to meet these objectives were specified in the August test matrix and included an inlet ESP gas flow of $10,200 \mathrm{scfm}$ at $300^{\circ} \mathrm{F}$ and $275^{\circ} \mathrm{F}$ with an ESP outlet particulate emission limit (pre-carbon injection) of $0.1-0.2$ $\mathrm{lb} / \mathrm{MBtu}$. These test conditions were continuously monitored through the ECTC DRG flow venturi and the outlet opacity and P-5A particulate monitors, and were regularly checked through EPA Method 2 (velocity traverse) and EPA Method 5 (outlet opacity) measurements. This gas flow was selected to maintain a representative gas flow residence time of 2-3 seconds through the first ESP field (" $\mathrm{A}$ " field), and a carbon residence time of 5 seconds from the point of injection to the exit of the first ESP field. The data used to determine the appropriate residence times for full-scale simulation testing are shown below in Table 2 . 


\begin{tabular}{|c|c|c|c|c|c|c|c|}
\hline $\begin{array}{l}\text { ESP INLET GAS FLOW } \\
(\mathrm{scfm})\end{array}$ & $\begin{array}{l}\text { TEMP. } \\
\text { (deg F) }\end{array}$ & $\begin{array}{l}\text { PRESSURE } \\
\text { (in. w.c.) } \\
\end{array}$ & $\begin{array}{c}\text { ESP INLET GAS FLOW } \\
(\mathrm{acfm})\end{array}$ & \begin{tabular}{|c|} 
INLET DUCT VEL \\
$(\mathrm{ft} / \mathrm{min})$
\end{tabular} & $\begin{array}{l}\text { ESP VEL } \\
(\mathrm{ft} / \mathrm{min})\end{array}$ & $\begin{array}{l}\text { ESP GAS RESIDENCE TIME } \\
(\mathrm{sec})\end{array}$ & \begin{tabular}{|} 
GAS RESIDENCE TIME/ FIELD \\
$(\mathrm{sec})$
\end{tabular} \\
\hline 4000 & 220 & -10 & 5281 & 1682 & 88 & 47 & 9 \\
\hline 4000 & 250 & -10 & 5514 & 1756 & 92 & 45 & 9 \\
\hline 10200 & 220 & -20 & 13815 & 4400 & 230 & 18 & 4 \\
\hline 10200 & 250 & -20 & 14425 & 4594 & 240 & 17 & 3 \\
\hline 10200 & 300 & -20 & 15441 & 4917 & 257 & 16 & 3 \\
\hline 8000 & 275 & -10 & 11417 & 3636 & 190 & 22 & 4 \\
\hline 8000 & 300 & -10 & 11805 & 3760 & 197 & 21 & 4 \\
\hline 8000 & 320 & -10 & 12116 & 3859 & 202 & 21 & 4 \\
\hline 6000 & 300 & -20 & 9083 & 2893 & 151 & 27 & 5 \\
\hline 11000 & 300 & -20 & 16652 & 5303 & 278 & 15 & 3 \\
\hline
\end{tabular}

Table 2. ESP Gas Flow Residence Time

Flue gas sampling during this testing was conducted at the ESP inlet and outlet locations using EPA Method 101A for total vapor-phase mercury measurement in the ECTC flue gas stream. During this test period, all flue gas sampling was conducted at vapor-phase mercury levels as received from the NYSEG Kintigh Station flue gas (i.e., the flue gas was not spiked/doped with any additional mercury species (elemental or ionic). During this period, measurements of the vapor-phase concentrations for total mercury at the ESP inlet (without carbon injection) indicated baseline $\mathrm{Hg}$ levels of $2-6 \mu \mathrm{g} / \mathrm{Nm}^{3}$. With this data, the various representative carbon injection rates for the test matrix were calculated as shown in Table 3.

\begin{tabular}{|c|c|c|}
\hline Carbon Injection Rate (lb/Macf) & Carbon : Mercury Ratio (lb/lb) & Carbon Injection Rate (lb/hr) \\
\hline \hline 2 & $15,000: 1$ & 1.8 \\
\hline 5 & $24,000: 1$ & 4.6 \\
\hline 10 & $55,000: 1$ & 9.2 \\
\hline
\end{tabular}

Table 3. Calculated carbon injection rates 


\section{Mercury Removal}

As testing continued this month, the data from the gas sampling periods and the lab analysis was collected and analyzed to plot the mercury removals associated with the various carbon injection rates. This data is presented below in Figure 2 for $300^{\circ} \mathrm{F}$ testing and Figure 3 for $275^{\circ} \mathrm{F}$ testing.

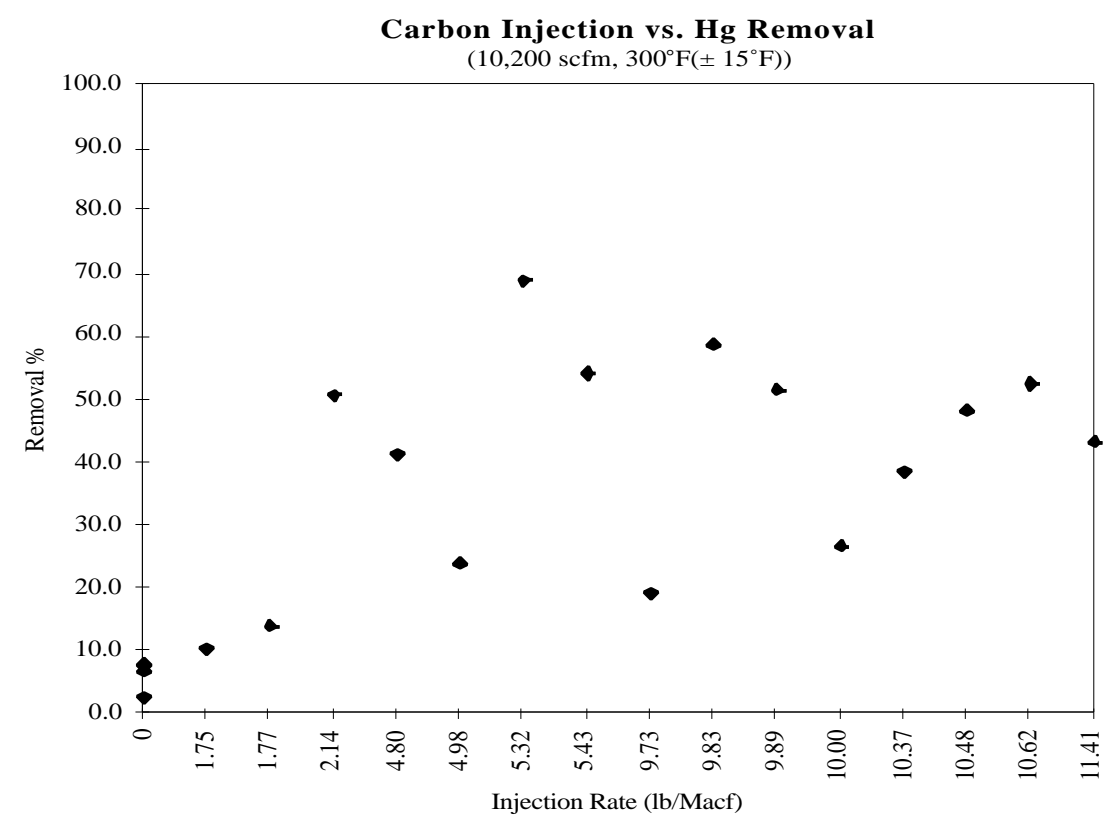

Figure 2. Total Mercury Removal vs. Carbon Injection, $300^{\circ} \mathrm{F}$.

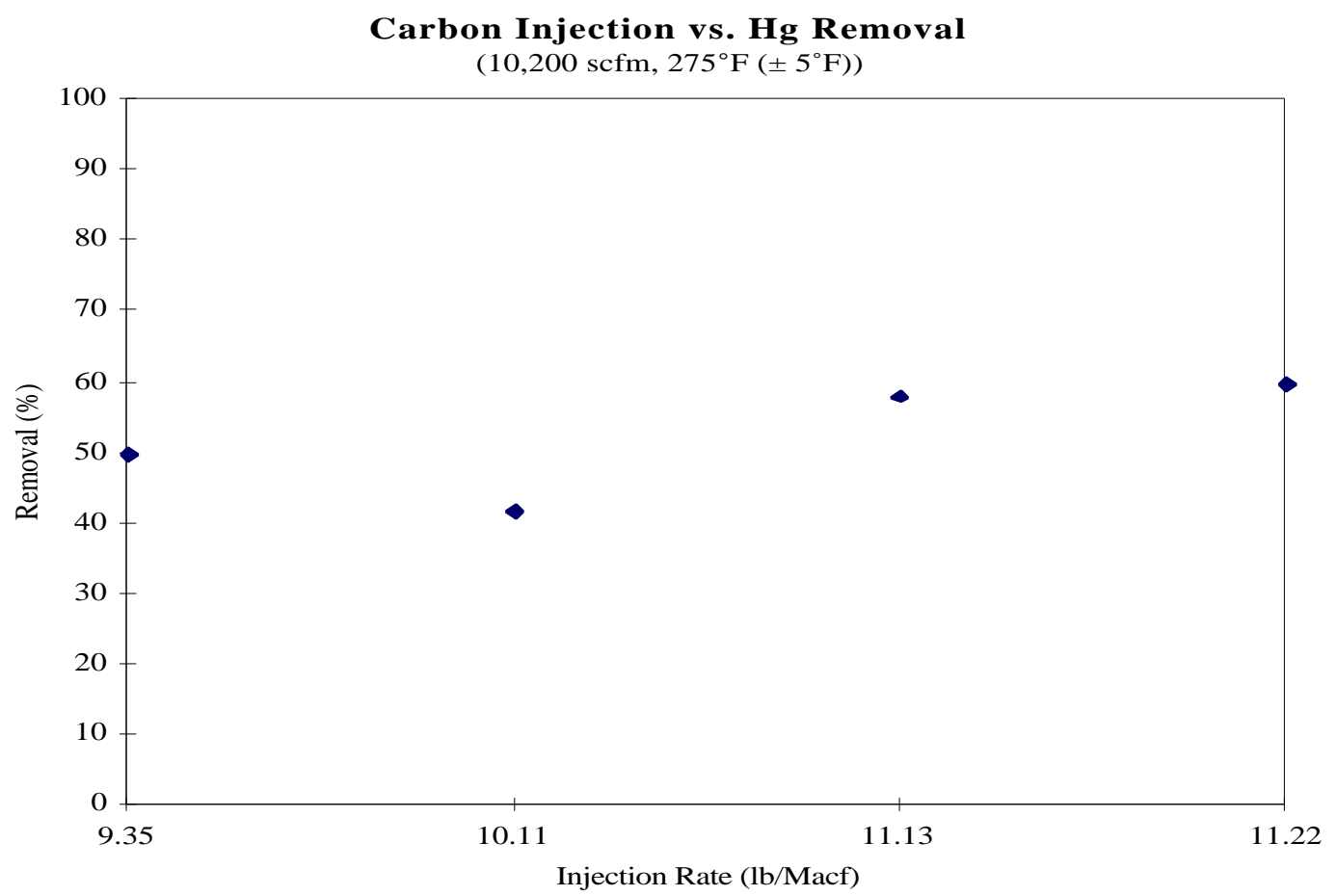

Figure 3. Total Mercury Removal vs. Carbon Injection, $275^{\circ} \mathrm{F}$. 
As the carbon injection rates were increased in the test matrix, higher removals for total vapor-phase mercury were obtained. From a review of the data plot and the raw data, an average removal efficiency was determined for each carbon injection rate. These efficiencies are shown in Table 4 below.

\begin{tabular}{|c|c|}
\hline Carbon Injection Rate (lb/Macf) & Average Mercury Removal Efficiency (\%) \\
\hline \hline 0 & 9 \\
\hline 2 & 12 \\
\hline 5 & 47 \\
\hline 10 & 43 \\
\hline 10 at $275^{\circ} \mathrm{F}$ & 52 \\
\hline
\end{tabular}

Table 4. Carbon Injection Rate vs. Average Mercury Removal

At the $5 \mathrm{lb} /$ Macf carbon injection range, an appreciable increase in total vapor-phase mercury removal was determined across the ESP, and the average removal efficiency was calculated at $47 \%$. However, there were only four data points taken at this point in the test matrix, and the analytical data from the samples collected during this injection rate was scattered and showed a wide range of mercury removal $(24 \%$ to $70 \%)$. Also, in reviewing the operating conditions period, it should be reported that the inlet flue gas temperature was allowed to fluctuate between a range of $285^{\circ} \mathrm{F}$ to $315^{\circ} \mathrm{F}$. As this may be a variable causing the scatter in the mercury removal data, additional samples will be taken during the test program with a more constant ESP inlet temperature of $300 \pm 5^{\circ} \mathrm{F}$.

At the $10 \mathrm{lb} /$ Macf carbon injection range, 4 more sample sets were collected during this test period. Based on the data, there did not appear to be an increase in total vapor-phase mercury removal, as the average removal efficiency for this period was calculated at $43 \%$. During this testing, the ESP inlet temperature was also allowed to fluctuate between $285^{\circ} \mathrm{F}$ to $315^{\circ} \mathrm{F}$.

At the other test condition (DSI-5) this month, the ESP inlet temperature was held constant at $275^{\circ} \mathrm{F}\left( \pm 5^{\circ} \mathrm{F}\right)$ using the SDA inlet heater. The carbon injection rate for this lower temperature test was $10 \mathrm{lb} /$ Macf. At this injection rate, 4 sample sets were taken. When compared to the $300^{\circ} \mathrm{F}$ average removal efficiency at $10 \mathrm{lb} / \mathrm{Macf}$, the data from the $275^{\circ} \mathrm{F}$ testing showed a higher average removal efficiency $(52 \%)$. The other carbon injection rates $(0,2,5 \mathrm{lb} / \mathrm{Macf})$ at $275^{\circ} \mathrm{F}$ are planned for testing next month.

\section{ESP Performance}

During the testing of activated carbon injection for total vapor-phase mercury removal this month, the effects of carbon injection on ESP performance were also measured. This effort was conducted during the baseline operating conditions during the period $(10,200 \mathrm{scfm}$ inlet ESP gas flow and an inlet ESP gas temperature of $300^{\circ} \mathrm{F} \pm 15^{\circ} \mathrm{F}$ and $\left.275^{\circ} \mathrm{F}\right)$. 
To study ESP performance, the ESP outlet opacity was continuously monitored (with and without carbon injection) through the use of several methods:

- Environmental Systems Corp. (ESC) P-5A mass concentration particulate monitor;

- regular EPA Method 5 gas samples, and;

- continuous $\%$ opacity readings.

Daily voltage/current (V/I) readings were also taken across each transformer rectifier (TR) set energized in the ESP, and weekly air load readings taken before each weekly start-up of the ESP. This data, when considered with the measurements taken on the flyash collected from the ESP ash hoppers (ash loss-onignition (LOI) content and $\mathrm{pH}$ ), allowed the impact of sorbent (carbon) injection to be characterized with respect to ESP performance.

The test data collected this month for ESP performance (at carbon injection rates of 0 - $10 \mathrm{lb}$./Macf and inlet gas temperatures of $300^{\circ} \mathrm{F}{ }^{ \pm} 15^{\circ} \mathrm{F}$ ) showed minimal effects on ESP outlet opacity. The results from the weekly air load readings on the ESP prior to each ESP start-up indicated no degradation or change in baseline settings, and the baseline V/I data for the ESP did not change. While it was noticed that there were some increases in the secondary voltages across the energized ESP fields during the high injection rates of carbon injection this period (resulting in improved ESP efficiency/decreased opacity), this data is scattered and needs additional review. Also, during this period, it was noticed that an significant amount of air inleakage across the ESP unit itself was occurring. An ESP outage was scheduled this test period to repair the ESP and reduce the amount of inleakage across the system.

\section{Future Testing}

Testing in September will continue with the Dry Sorbent Injection (DSI) investigation across the ECTC ESP. Based on the current test matrix, the September testing will investigate the effects of mercury removal and ESP performance at carbon injection rates of 0,2 , and $5 \mathrm{lb} / \mathrm{Macf}$, at a controlled inlet ESP gas temperature of $275^{\circ} \mathrm{F} \pm 5^{\circ} \mathrm{F}$. Also, the number of data points / sample points per each injection rate will be increased next month. As this test series is completed, some data points in the $300^{\circ} \mathrm{F}$ test matrix will be repeated with more attention placed on controlling inlet ESP gas temperature. 
APPENDIX A

TEST SCHEDULE(S) 


\begin{tabular}{|c|c|c|c|c|c|c|c|c|c|c|c|c|c|}
\hline & \multicolumn{13}{|c|}{1996} \\
\hline & JAN & FEB & MAR & APR & MAY & JUN & JUL & AUG & SEP & OCT & NOV & & \\
\hline $\begin{array}{l}\text { 4.0 MW Pilot } \\
\text { FGD Unit }\end{array}$ & \multicolumn{2}{|c|}{$\begin{array}{l}\text { EPRI Wet FGD } \\
\text { Toxics Testing }\end{array}$} & $\begin{array}{l}\mathrm{DOE} / \mathrm{h} \\
\text { Mercu } \\
\text { Contro }\end{array}$ & $\begin{array}{l}\text { DA Pha } \\
\text { and HA } \\
\text { with We } \\
\end{array}$ & & \multicolumn{2}{|c|}{$\begin{array}{l}\text { EPRI Wet FGD } \\
\text { Toxics Testing }\end{array}$} & \begin{tabular}{|l} 
Thin \\
Tes \\
Rot \\
Tec
\end{tabular} & & $\begin{array}{c}\text { EPRI Toxics } \\
\text { Removal } \\
\text { Testing } \\
\end{array}$ & \multicolumn{2}{|c|}{$\begin{array}{l}\text { EPRI } \\
\text { SOx/NOx } \\
\text { Process } \\
\text { Testing } \\
\end{array}$} & \begin{tabular}{|l} 
ECTC \\
Fall \\
Outage
\end{tabular} \\
\hline $\begin{array}{l}\text { 0.4 MW Mini- } \\
\text { Pilot FGD Unit }\end{array}$ & \multicolumn{2}{|c|}{ UNIT DOWN } & \multicolumn{11}{|c|}{ DOE/PRDA Phase I - Multiple Pollutant Removal Using the Condensing Heat Exchanger (CHX) } \\
\hline
\end{tabular}

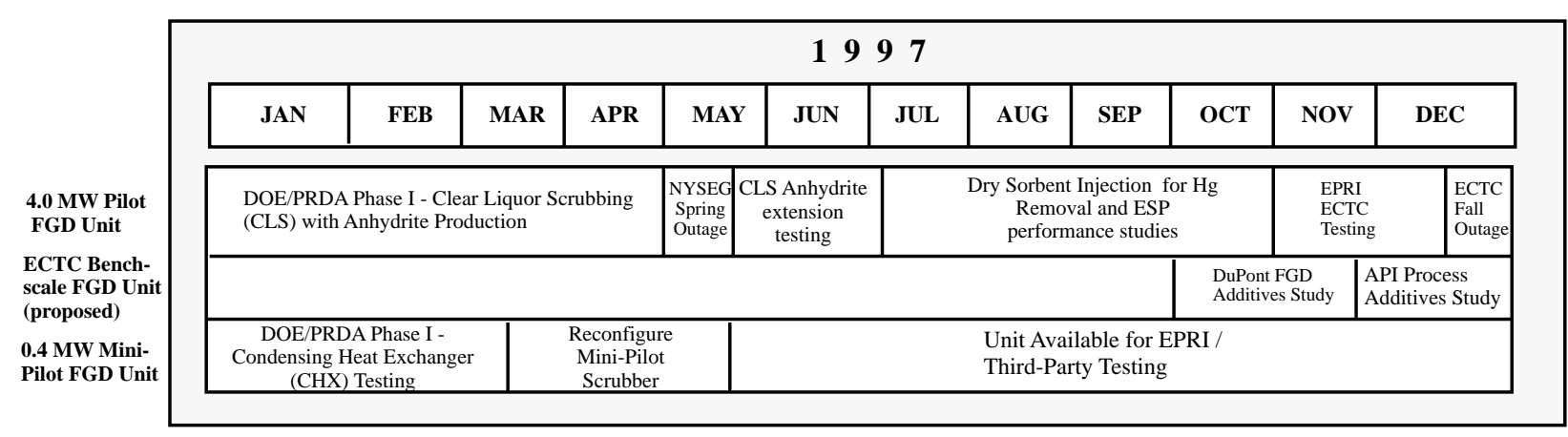

\begin{tabular}{|c|c|c|c|c|c|c|c|c|c|c|c|c|}
\hline & \multicolumn{12}{|c|}{1998 (proposed) } \\
\hline & JAN & FEB & MAR & APR & MAY & JUN & JUL & AUG & SEP & OCT & NOV & DEC \\
\hline $\begin{array}{l}\text { 4.0 MW Pilot } \\
\text { Wet FGD Unit }\end{array}$ & \multicolumn{6}{|c|}{$\begin{array}{c}\text { DOE/PRDA Phase II } \\
\text { Clear Liquor Scrubbing with Anhydrite }\end{array}$} & \multicolumn{3}{|c|}{$\begin{array}{l}\text { DOE/PRDA Phase II } \\
\text { Condensing Heat Exchanger } \\
\text { (CHX) Testing }\end{array}$} & \multicolumn{3}{|c|}{ EPRI / Third-Party Testing } \\
\hline $\begin{array}{l}\text { 0.4 MW Mini- } \\
\text { Pilot FGD Unit }\end{array}$ & \multicolumn{12}{|c|}{ EPRI / Third-Party Testing } \\
\hline
\end{tabular}

ECTC Test Schedule ('96 - '98) 
APPENDIX B

PROCESS/ANALYTICAL DATA SUMMARY 
EPRI/EPDC

Dry Sorbent Injection across the ESP

Data Summary

\begin{tabular}{|c|c|c|c|c|c|c|c|c|c|c|c|c|c|c|c|c|c|c|c|}
\hline Test & Date & $\begin{array}{c}\text { Sample } \\
\text { ID }\end{array}$ & $\begin{array}{l}\text { Sampling } \\
\text { Location } \\
\end{array}$ & Time & $\begin{array}{c}\mathrm{Hg} \\
\left(\mathrm{ug} / \mathrm{Nm}^{3}\right) \\
\end{array}$ & $\begin{array}{c}\text { Removal } \\
(\%)\end{array}$ & Hg in Ash & $\begin{array}{l}\mathrm{C}: \mathrm{Hg}^{*} \\
(\#: 1) \\
\end{array}$ & $\begin{array}{r}\text { Carbon } \\
(\mathrm{lb} / \mathrm{hr}) \\
\end{array}$ & $\begin{array}{l}\text { Opacity } \\
(\%)\end{array}$ & $\begin{array}{c}\text { Mass Loading } \\
\text { (lb/MMBtu) }\end{array}$ & $\begin{array}{c}\mathrm{P}-5 \mathrm{~A} \\
(\mathrm{mg} / \mathrm{m} 3) \\
\end{array}$ & $\begin{array}{c}\text { P-5A } \\
\text { (lb/MMBtu) }\end{array}$ & $\begin{array}{c}\text { NYSEG } \\
(\mathrm{MW})\end{array}$ & $\begin{array}{c}\text { S02 Inlet } \\
\text { (ppm) }\end{array}$ & $\begin{array}{c}\text { S02 Outlet } \\
(\mathrm{ppm})\end{array}$ & $\begin{array}{c}\text { Difference } \\
(\%)\end{array}$ & $\begin{array}{c}\text { ESP Efficiency ** } \\
(\%)\end{array}$ & $\begin{array}{c}\text { Inj. Efficies } \\
(\%) \\
\end{array}$ \\
\hline \multicolumn{20}{|c|}{ Carbon Injection $10 \mathrm{lb} / \mathrm{Macf}(10200 \mathrm{scfm}, 300 \mathrm{~F}, 9.2 \mathrm{lb} / \mathrm{hr})$} \\
\hline DSI-4 & $8 / 1 / 97$ & M-041 & ESP-In & $8: 50$ & 4.19 & 58.9 & - & 59533 & 9.04 & 4.81 & - & 56 & 0.111 & 589 & 1292 & 1044 & 19 & 97 & - \\
\hline DSI-4 & $8 / 1 / 97$ & $\mathrm{M}-042$ & ESP-Out & $8: 50$ & 1.72 & - & - & 59533 & 9.04 & 4.81 & - & 56 & 0.111 & 589 & 1292 & 1044 & 19 & 97 & - \\
\hline DSI-4 & $8 / 1 / 97$ & $\mathrm{M}-043$ & ESP-In & 10:00 & 3.85 & 51.7 & - & 65220 & 9.10 & 4.23 & - & 55 & 0.109 & 571 & 1246 & 1013 & 19 & 97 & - \\
\hline DSI-4 & $8 / 1 / 97$ & M-044 & ESP-Out & 10:00 & 1.86 & - & - & 65220 & 9.10 & 4.23 & - & 55 & 0.109 & 571 & 1246 & 1013 & 19 & 97 & - \\
\hline DSI-4a & $8 / 4 / 97$ & P-011 & ESP-Out & 849 & - & - & - & 0 & 0.00 & 2.34 & 0.176 & 47 & 0.059 & 708 & 1374 & 1172 & 15 & 96 & - \\
\hline DSI-4a & $8 / 6 / 97$ & P-012 & ESP-Out & 9:00 & - & - & - & 0 & 0.00 & 2.65 & 0.188 & 81 & 0.100 & 575 & 1403 & 1162 & 17 & 95 & - \\
\hline DSI-4b & $8 / 7 / 97$ & P-013 & ESP-Out & 10:00 & - & - & - & 64105 & 9.20 & 3.12 & 0.170 & 80 & 0.098 & 690 & 1474 & 1204 & 18 & 96 & - \\
\hline DSI-4b & $8 / 11 / 97$ & P-014 & ESP-Out & $8: 32$ & - & - & - & 0 & 0.00 & 3.78 & 0.208 & 322 & 0.395 & 684 & 1495 & 1247 & 17 & 95 & - \\
\hline DSI-4b & $8 / 13 / 97$ & P-015 & ESP-Out & $8: 57$ & - & - & - & 0 & 0.00 & 3.13 & 0.221 & 297 & 0.369 & 707 & 1425 & 1169 & 18 & 94 & - \\
\hline DSI-4c & $8 / 18 / 97$ & P-016 & ESP-Out & 10:45 & - & - & - & 0 & 0.00 & 5.62 & 0.196 & 340 & 0.427 & 610 & 1289 & 1108 & 14 & 95 & - \\
\hline DSI- $4 \mathrm{c}$ & $8 / 19 / 97$ & P-017 & ESP-In & 10:13 & - & - & - & 64105 & 9.20 & 5.97 & 4.867 & 164 & 0.204 & 694 & 1483 & 1247 & 16 & - & - \\
\hline DSI-4c & $8 / 20 / 97$ & M-045 & ESP-In & $8: 42$ & 3.54 & 43.5 & - & 81844 & 10.50 & 5.70 & - & 165 & 0.086 & 514 & 1237 & 1037 & 16 & 98 & 56 \\
\hline DSI-4c & $8 / 20 / 97$ & M-046 & ESP-Out & $8: 43$ & 2 & - & - & 81844 & 10.50 & 5.70 & - & 165 & 0.086 & 514 & 1237 & 1037 & 16 & 98 & 56 \\
\hline DSI-4c & $8 / 20 / 97$ & M-047 & ESP-In & $9: 58$ & 3.4 & 19.4 & - & 72635 & 8.95 & 5.94 & - & 170 & 0.089 & 478 & 1323 & 1112 & 16 & 98 & 55 \\
\hline DSI- $4 \mathrm{c}$ & $8 / 20 / 97$ & M-048 & ESP-Out & 10:00 & 2.74 & - & - & 72635 & 8.95 & 5.94 & - & 170 & 0.089 & 478 & 1323 & 1112 & 16 & 98 & 55 \\
\hline \multicolumn{20}{|c|}{ Carbon Injection $10 \mathrm{lb} / \mathrm{Macf}(10200 \mathrm{scfm}, 275 \mathrm{~F}, 9.2 \mathrm{lb} . / \mathrm{hr}$.) } \\
\hline DSI-5 & $8 / 26 / 97$ & P-018 & ESP-Out & $8: 58$ & - & - & - & 0 & 0.00 & 3.44 & 0.301 & 244 & 0.295 & 690 & 1596 & 1333 & 16 & 92 & - \\
\hline DSI-5 & $8 / 27 / 97$ & P-019 & ESP-Out & $8: 17$ & - & - & - & 0 & 0.00 & 1.99 & 0.104 & 146 & 0.176 & 684 & 1591 & 1363 & 14 & 97 & - \\
\hline DSI-5 & $8 / 28 / 97$ & M-049 & ESP-In & $8: 20$ & 6.56 & 58.2 & - & 43072 & 10.24 & 1.44 & - & 108 & 0.077 & 667 & 1573 & 1343 & 15 & 98 & 26 \\
\hline DSI-5 & $8 / 28 / 97$ & M- -050 & ESP-Out & $8: 20$ & 2.74 & - & - & 43072 & 10.24 & 1.44 & - & 108 & 0.077 & 667 & 1573 & 1343 & 15 & 98 & 26 \\
\hline DSI-5 & $8 / 28 / 97$ & M-051 & ESP-In & $9: 35$ & 6.3 & 59.5 & - & 45200 & 10.32 & 1.37 & - & 106 & 0.076 & 693 & 1603 & 1413 & 12 & 98 & 27 \\
\hline DSI-5 & $8 / 28 / 97$ & M-052 & ESP-Out & $9: 36$ & 2.55 & - & - & 45200 & 10.32 & 1.37 & - & 106 & 0.076 & 693 & 1603 & 1413 & 12 & 98 & 27 \\
\hline DSI-5 & $8 / 29 / 97$ & M- -053 & ESP-In & $7: 50$ & 4.19 & 42.0 & - & 61245 & 9.30 & 1.52 & - & 112 & 0.080 & 477 & 1347 & 1136 & 16 & 98 & 23 \\
\hline DSI-5 & $8 / 29 / 97$ & M-054 & ESP-Out & $7: 50$ & 2.43 & - & - & 61245 & 9.30 & 1.52 & - & 112 & 0.080 & 477 & 1347 & 1136 & 16 & 98 & 23 \\
\hline DSI-5 & $8 / 29 / 97$ & M-055 & ESP-In & $9: 02$ & 3.88 & 49.7 & - & 61160 & 8.60 & 1.67 & - & 118 & 0.084 & 478 & 1351 & 1137 & 16 & 98 & 19 \\
\hline DSI-5 & $8 / 29 / 97$ & M- -056 & ESP-Out & 9:02 & 1.95 & - & - & 61160 & 8.60 & 1.67 & . & 118 & 0.084 & 478 & 1351 & 1137 & 16 & 98 & 19 \\
\hline
\end{tabular}




\section{ECTC COSPONSORS DISTRIBUTION}

Mr. John E. Smigelski

New York State Electric \& Gas

Corporate Drive, Kirkwood Ind. Park

P. O. Box 5224

Binghamton, NY 13902-5224

Ph: (607) 762-8688

Fax: (607) 762-8457

Dr. Gerald Janik

New York State Electric \& Gas

Corporate Drive, Kirkwood Ind. Park

P. O. Box 5224

Binghamton, NY 13902-5224

Ph: (607) 762-4318

Fax: (607) 762-8457
Ms. JoAnn C. Zysk

U.S. Department of Energy

Federal Energy Technology Center

P. O. Box 10940, MS 900-33

Pittsburgh, PA 15236

Ph: (412) 892-6200

Fax: (412) 892-6216

Mr. Michio Kurihara

Electric Power Development Co., Ltd.

15-1, Ginza 6-Chome, Chuo-ku

Tokyo, 104 JAPAN

Ph: (81) 3-3546-9404

Fax: (81) 3-3546-9482

Ms. Debra DiMeo

Empire State Electric Energy Res. Corp.

1515 Broadway

New York, NY 10036

Ph. (212) 302-1212

Fax: (212) 302-1377

\section{EPRI DISTRIBUTION}
G. Andes
T. Armor
M. Miller
G. Offen
R. Rhudy W. Chow
R. Glover 